\title{
Analisa Pengaruh Absorpsi Air Laut Terhadap Kekuatan Tarik Komposit Serat Pelepah Sawit
}

\author{
Zulkifli $^{1, a}$, Hadi Hermansyah ${ }^{1, b}$ dan Syahruddin ${ }^{1, c}$ \\ ${ }^{1}$ Jurusan, Teknik Mesin, Politeknik Negeri Balikpapan, Jl. Soekarno Hatta Km. 8, Balikpapan 76126 \\ ${ }^{\mathrm{a}}$ zulkifli.as@poltekba.ac.id \\ b hermansyah_hadi@yahoo.com \\ c syahruddin@poltekba.ac.id
}

\begin{abstract}
This study aims to analyze the absorption of sea water on Composite Materials palm frond fibers per 24 hours for 9 days and analyze the effect of immersion for 3, 6, and 9 days of the tensile strength fiber-reinforced composite material of palm fronds. The polymers used type of epoxy resin. Palm frond fibers arranged randomly, then fiber treated alkali $5 \%$ for 2 hours, and then molded with a size of $200 \times 200 \times 5 \mathrm{~mm}$ with a ratio between matrix and fiber is 90:10 to press molding tool. Composite plates immersed in a container filled with sea water aquarium for 3, 6, and 9 days and every 24 hours of material in weigh, test procedures seawater absorption refers to the ASTM D 570 - 98. As well as every 3, 6, and 9 days plate removed and cut into a polymer composite beam according to the standard ASTM D63802 (type 1). Each variable will be tested for 3 times. Based on the test results get soaking in the absorption rate reached its peak in the first day, namely $0.26 \%$ for the first specimen testing threeday, $0.5 \%$ for the second specimen testing 6 days and $0.25 \%$ for the third specimen testing nine days. Then it will go on steadily and decreases until it reaches saturation point. Where for the first specimen in the third day of absorption of $0.49 \%$, a second specimen in the sixth day of absorption of $1.71 \%$, and the third specimen in the esembilan absorption $0.93 \%$. And the influence of sea water immersion tensile strength fiber Composite palm fronds have a dynamic effect on the test results before immersion up to 9 days of immersion that is power up and down. With a value of $15.468 \mathrm{MPa}$ before immersion, 17.046 MPa 3 days of immersion, 15.107 MPa 6 day immersion, and 21.137 MPa 9 days of immersion.
\end{abstract}

Keywords - Composites, epoxy resins, fibers of palm fronds, ASTM

Abstrak- Penelitian ini bertujuan untuk menganalisa daya penyerapan air laut pada Material Komposit serat pelepah sawit per 24 jam selama 9 hari dan menganalisis pengaruh perendaman selama 3, 6, dan 9 hari terhadap kekuatan tarik material komposit diperkuat serat pelepah sawit.. Polimer yang digunakan jenis resin epoksi. Jenis serat pelepah sawit yang disusun acak, selanjutnya serat diberi perlakuan alkali $5 \%$ selama 2jam, lalu dicetak dengan ukuran 200 x 200x $5 \mathrm{~mm}$ dengan perbandingan antara matriks dan serat yaitu 90:10 dengan alat press molding. Lalu pelat komposit direndam dalam wadah akuarium yang berisi air laut selama 3, 6, dan 9 hari dan setiap 24 jam material di timbang, prosedur pengujian penyerapan air laut ini mengacu pada ASTM D 570 - 98. Serta setiap 3, 6, dan 9 hari pelat diangkat dan dipotong membentuk balok komposit polimer sesuai standar ASTM D638-02 (type 1). Setiap variabel akan diuji sebanyak 3 kali. Berdasarkan pengujian perendapan di dapatkan hasil Laju penyerapan mencapai kenaikan tertinggi pada hari pertama yaitu $0,26 \%$ untuk spesimen pertama pengujian 3 hari, $0,5 \%$ untuk spesimen kedua pengujian 6 hari dan $0,25 \%$ untuk spesimen ketiga pengujian 9 hari. Kemudian akan berlangsung stabil dan menurun sampai mencapai titik jenuh. Dimana untuk spesimen pertama di hari ketiga penyerapannya $0,49 \%$, spesimen kedua di hari keenam penyerapannya $1,71 \%$, dan spesimen ketiga di hari kesembilan penyerapannya $0,93 \%$. Dan pengaruh perendaman air laut terhadap kekuatan tarik komposit berpenguat serat pelepah sawit ini memiliki dampak yang dinamis untuk hasil uji sebelum perendaman sampai ke 9 hari perendaman yaitu kekuatan yang naik dan turun. Dengan nilai 15,468 MPa sebelum perendaman, 17,046 MPa 3 hari perendaman, 15,107 MPa 6 hari perendaman, dan 21,137 MPa 9 hari perendaman. ASTM

Kata Kunci-Komposit, resin epoksi, serat pelepah sawit,

\section{Pendahuluan}

\section{A. Latar Belakang}

Indonesia adalah negara kepulauan terbesar di dunia, menurut data Departemen Dalam Negeri Republik Indonesia tahun 2004, Indonesia memiliki sebanyak 17.504 buah pulau dan 7.870 di antaranya telah mempunyai nama, sedangkan 9.634 belum memiliki nama. Sejalan dengan itu pada tahun 2009, jumlah nelayan di Indonesia tercatat 2.752 .490 orang dengan total armada 596.230 unit. Dari jumlah nelayan tersebut 
90\%nya merupakan nelayan kecil dengan bobot mati kapal di bawah 30 Gross Tonnage (GT) [1].

Sejalan dengan banyaknya jumlah nelayan tangkap indonesia sehingga banyak pula jumlah kapal yang di butuhkan untuk digunakan dalam penangkapan ikan, menurut data dari Badan Pusat Statistik Indonesia (BPS) pada tahun 2010 jumlah kapal/perahu penagkap ikan mencapai 742,369 buah perahu/kapal. Dimana jumlah ini terdiri dari 570,827 buah perahu/kapal penagkap ikan di laut dan 171,542 buah perahu/kapal penagkap ikan di perairan umum [2].

Sampai saat ini sarana yang digunakan di laut masih sangat tergantung dari bahan baku kayu Namun kekuatan kayu dipengaruhi salah satunya oleh kadar air yang dikandung kayu tersebut. Perendaman kayu pada air laut mengakbatkan meningkatnya kadar garam dalam kayu sebesar 0,6\% s/d 2,5\% tetapi akibat meningkatnya kadar garam ini mengakibatkan penurunan kekuatan kayu : sebesar $1,33 \%$ s/d 16,10\% terhadap kuat tekan kayu tanpa perendaman; 3,42\% s/d 23,29\% terhadap kuat tarik kayu tanpa perendaman dan sebesar 1,36\% s/d 20,85\% terhadap kuat lentur kayu tanpa perendaman [3].

Penggunaan Polimer dan komposit dewasa ini kian meningkat di segala bidang kehidupan seperti untuk pembuatan kapal. Namun komposit polimer mempunyai sifat akan kemampuan menyerap air jika berada di udara lembab atau ketika polimer tersebut dicelupkan di dalam air (Water-absorption).Water-absorption pada komposit berpenguat serat alami memiliki beberapa pengaruh yang merugikan dalam propertiesnya dan mempengaruhi kemampuannya dalam jangka waktu yang lama juga penurunan secara perlahan dari ikatan interface komposit serta menurunkan sifat mekanis komposit seperti kekuatan tariknya. Penurunan ikatan interface komposit menyebabkan penurunan properties mekanis komposit tersebut [4]. Water absorbtion dalam komposit merupakan kemampuan komposit dalam menyerap uap air dalam waktu tertentu. Water absorbtion pada komposit merupakan salah satu masalah terutama dalam penggunaan komposit di luar ruangan [5].

Kelapa sawit merupakan salah satu komoditas perkebunan yang perkembangannya cukup pesat dibandingkan dengan komoditas lain terutama terjadi di
Sumatera dan Kalimantan. Untuk seluruh Indonesia, pada tahun 1968 luas areal yang baru 120 ribu ha menjadi 4926 ribu ha pada tahun 2003. Selain dari pertumbuhan areal yang cukup besar tersebut, hal lain yang lebih mendasar lagi adalah penyebarannya, yang semula hanya ada pada 3 propinsi saja di Sumatera, tetapi saat ini telah tersebar di 17 propinsi di Indonesia. Sumatera masih memiliki areal terluas di Indonesia, yaitu mencapai $75,98 \%$ diikuti Kalimantan dan Sulawesi, masing-masing 20,53\% dan 2,81\%) [6]. Pelepah sawit sebagai hasil limbah padat perkebunan sawit merupakan sumber bahan berlignoselulosa yang sangat potensial), tersedia sekitar10 ton/ha/tahun limbah pelepah kering hasil pemangkasan . Pembuatan komposit yang diperkuat serat alami (pelepah sawit) dimaksud untuk mencari alternatif material komposit yang tidak tergantung pada serat sintetis [7].

Tujuan yang hendak dicapai dalam penelitian ini yaitu menganalisa daya penyerapan air laut pada Material Komposit serat pelepah sawit per 24 jam selama 9 hari dan menganalisis pengaruh perendaman selama 3, 6, dan 9 hari terhadap kekuatan tarik material komposit diperkuat serat pelepah sawit.

\section{Metode Penelitian}

\section{A. Metode Penelitian}

Material utama dari penelitian ini yaitu, resin tipe epoksi. Resin epoksi dan hardener diperoleh dari PT. Justus Kimia Raya. Dan jenis serat yang digunakan serat pelepah sawit dengan susunan acak.

Pembuatan papan komposit dengan perbandingan matriks dan serat 90:10 dengan ukuran $200 \times 200 \times 5$ $\mathrm{mm}$ dicetak di Laboratorium Pengujian Bahan jurusan mesin Politeknik Negeri Balikpapan dengan menggunakan alat press molding. Dimana sebelum di cetak serat pelepah sawit pertama kali diberi perlakuan alkali 5\% selama 2 jam.

Hasil cetakan yang berupa pelat lalu direndam di dalam wadah yang berisi air laut selama 3, 6 dan 9 hari. Berdasarkan standar ASTM D570-98 dan data pertambahan berat spesimen diambil tiap 24 jam selama 3, 6 dan 9 hari. Setelah dilakukan perendaman pelat komposit tersebut dibentuk sesuai standar ASTM D638- 
02 (type 1) sebanyak 3 spesimen tarik untuk tiap pelat komposit .

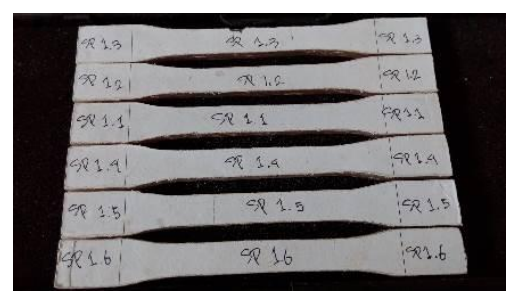

Gambar 1. Spesimen Uji Tarik ASTM D638-02 (type 1)

\section{B. Gambar Diagram Alir Penelitian}

Adapun gambar diagram alir penelitian ini dapat dilihat di bawah ini.

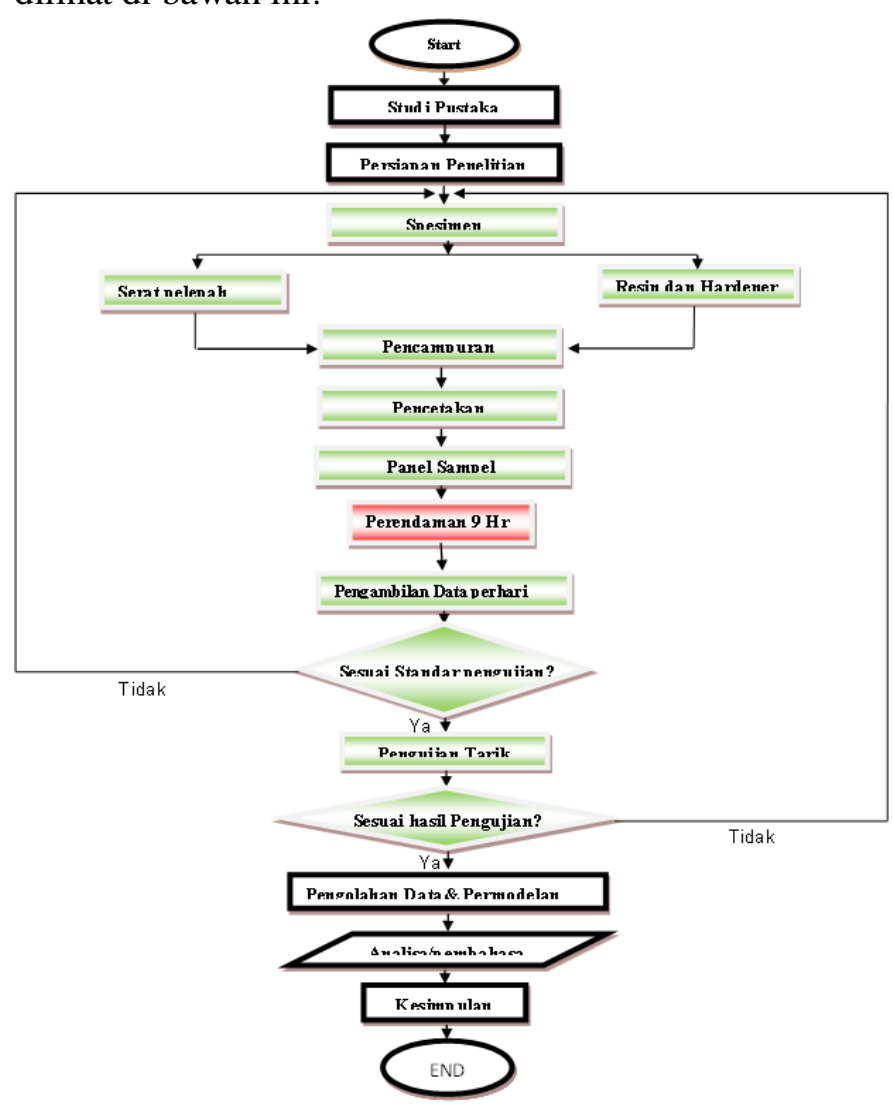

Gambar 2. Diagram Alir Penelitian

\section{Hasil dan Pembahasan}

\section{A. Hasil Perendaman Material Komposit}

Dalam penelitian ini dilakukkan uji serap air laut pada material komposit selama 9 hari lamanya. Material yang di rendam ada 3 buah yang mana dibagi menjadi material untuk 3 hari, 6 hari, dan 9 hari. adapun hasil perendaman dapat dilihat dalam diagram berikut:

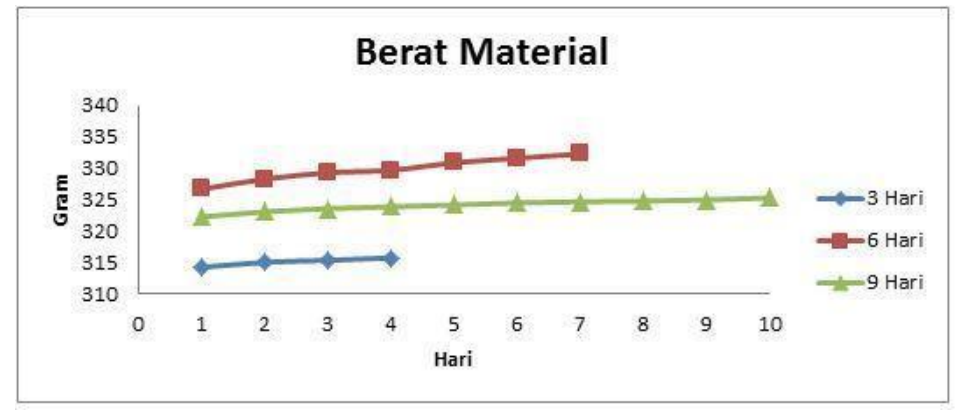

Gambar 3. Diagram pertambahan berat spesimen

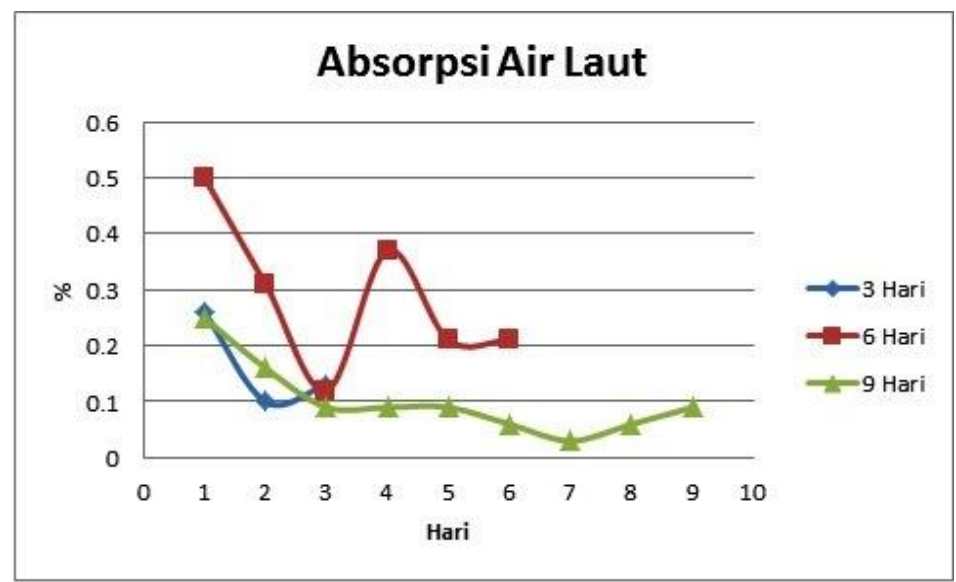

Gambar 4. Diagram absorpsi air laut

Dari hasil diatas dapat disimpulkan bahwa laju penyerapan komposit berpenguat serat pelepah sawit ini, yaitu: Titik tertinggi penyerapan terjadi pada hari pertama, semuanya menunjukkan nilai penyerapan tertinggi yaitu spesimen 3 hari dengan 0,26\% kemudian spesimen 6 hari $0,50 \%$ serta spesimen 9 hari $0,25 \%$. Hal ini dikarenakan pada hari pertama pori-pori komposit pertama kali terisi. Berbeda jika pori-pori sudah terisi, maka laju penyerapan akan melambat dikarenakan pertambahan berat hanya terjadi karena serat (fiber) yang menyerap air. Dan dari ketiga spesimen, ketiganya menunjukkan kenaikkan dengan nilai yang bervariasi, hal ini disebabkan oleh pori-pori serta tereksposnya serat pada air laut yang diakibatkan masing-masing spesimen memiliki pori-pori serta serat yang terekspos berbeda.

\section{B. Kekuatan Tarik}

Adapun hasi pengujian tarik dari ketiga spesimen (sebelum perendaman, 3 Hari, 6 Hari dan 9 Hari perendaman) didapat hasil sebagai berikut: 




Gambar 5.Diagram Tegangan Tarik

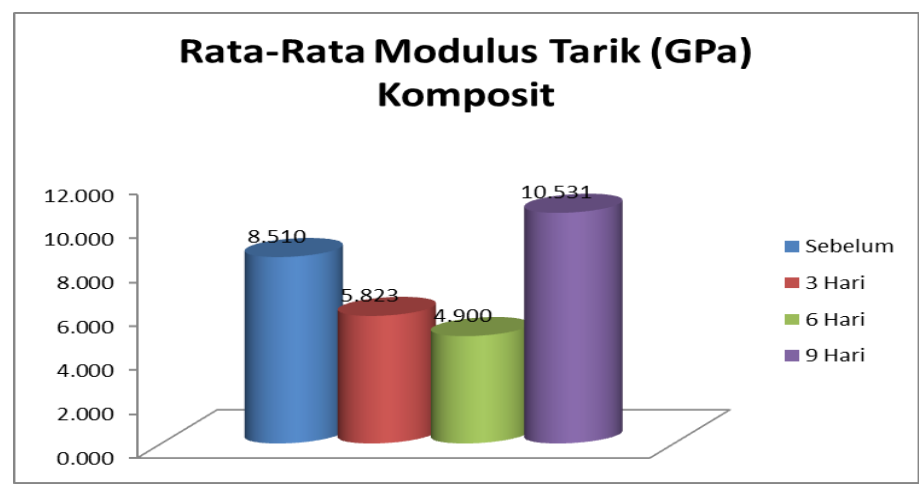

Gambar 6. Diagram Modulus Tarik

Dari hasil uji menunjukkan terjadi perubahan sifat mekanik yang dinamik, dari sebelum di rendam, 3 hari perendaman, 6 hari perendaman, dan 9 hari perendaman. Hal ini terjadi karena perubahan kekuatan ini bersifat normal karena kekuatan ini sendiri berhubungan dengan laju penyerapan. Laju penyerapan sendiri berhubungan dengan perubahan kekuatan dikarenakan komposit berpenguat serat alam akan menyebabkan turunnya sifat mekanis materialnya. Dan juga laju penyerapan akan berhenti saat mencapai titik jenuh yaitu antara $11 \%$ $12 \%$. Hasil yang dinamik naik turun pada gambar dikarenakan penyerapan komposit belum mencapai titik jenuh sehingga perubahan akan sifat mekanis material masih mungkin terjadi.

\section{Pengamatan Foto Makro}

Berdasarkan hasil foto makro pada material komposit uji tarik dan impak, maka diketahui pola patahan komposit cenderung mengalami patah getas (brittle), hal tersebut terlihat pada permukaan penampang patahan yang kelihatan mengkilap seperti bercahaya. Hal ini menandakan patahan yang terjadi adalah patah getas atau brittle dengan cenderung mengalami mekanisme fiber pull Out. Penyebab terjadinya fiber pull out adalah kurang kuatnya ikatan interface antara serat dan matrik dan pengaruh dari perlakuan alkali $(\mathrm{NaOH})$

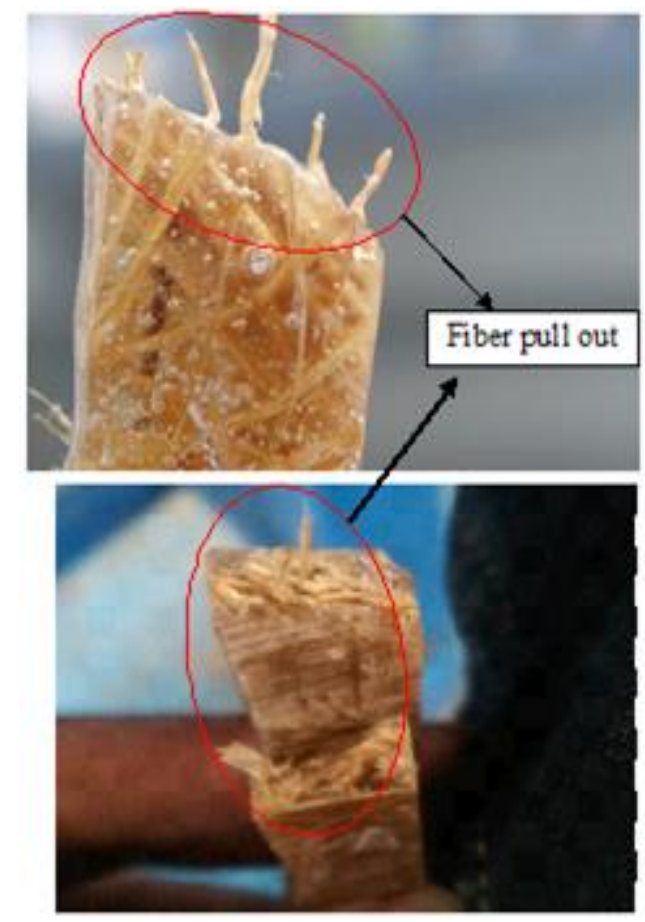

Gambar 7. Fiber pull out

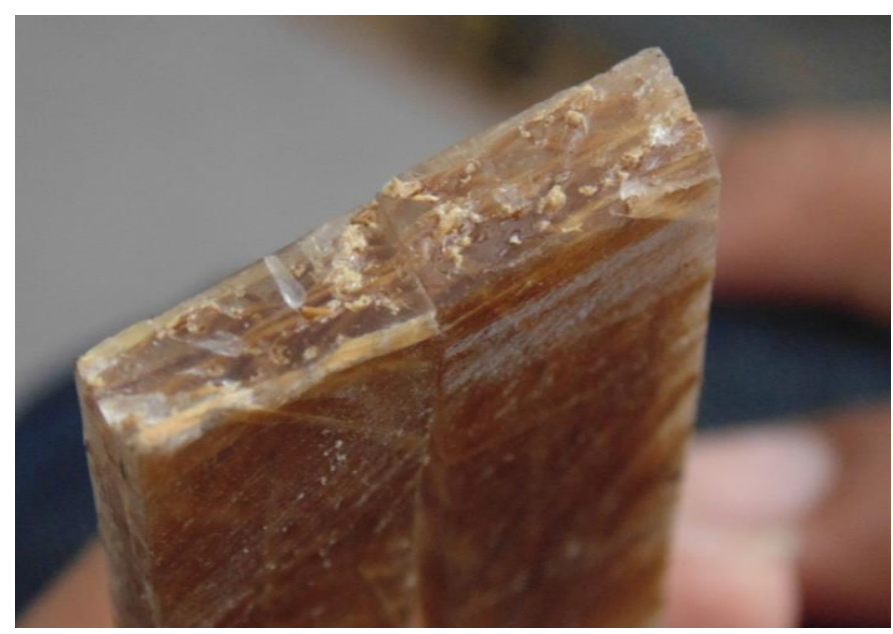

Gambar 8. Penampang patahan material

\section{Pengamatan SEM}

Untuk mendapatkan gambaran yang lebih nyata terhadap modus kerusakan sampel uji komposit serat pelepah sawit epoksi, dilakukan foto SEM (Scanning Electron Microscope) terhadap sampel uji tarik. Pada 
gambar 9 (a), (b), (c), dan (d) memperlihatkan serat pelepah sawit putus diakibatkan oleh adanya gaya tarik yang didapat oleh matriks lalu diteruskan ke serat pelepah sawit. Pada material juga terbentuk void seperti yang di perlihatkan pada gambar 9 (b) dan hampir diseluruh material terbentuk void sehingga void tersebut mempengaruhi kekuatan tarik dari material komposit berserat pelepah sawit.

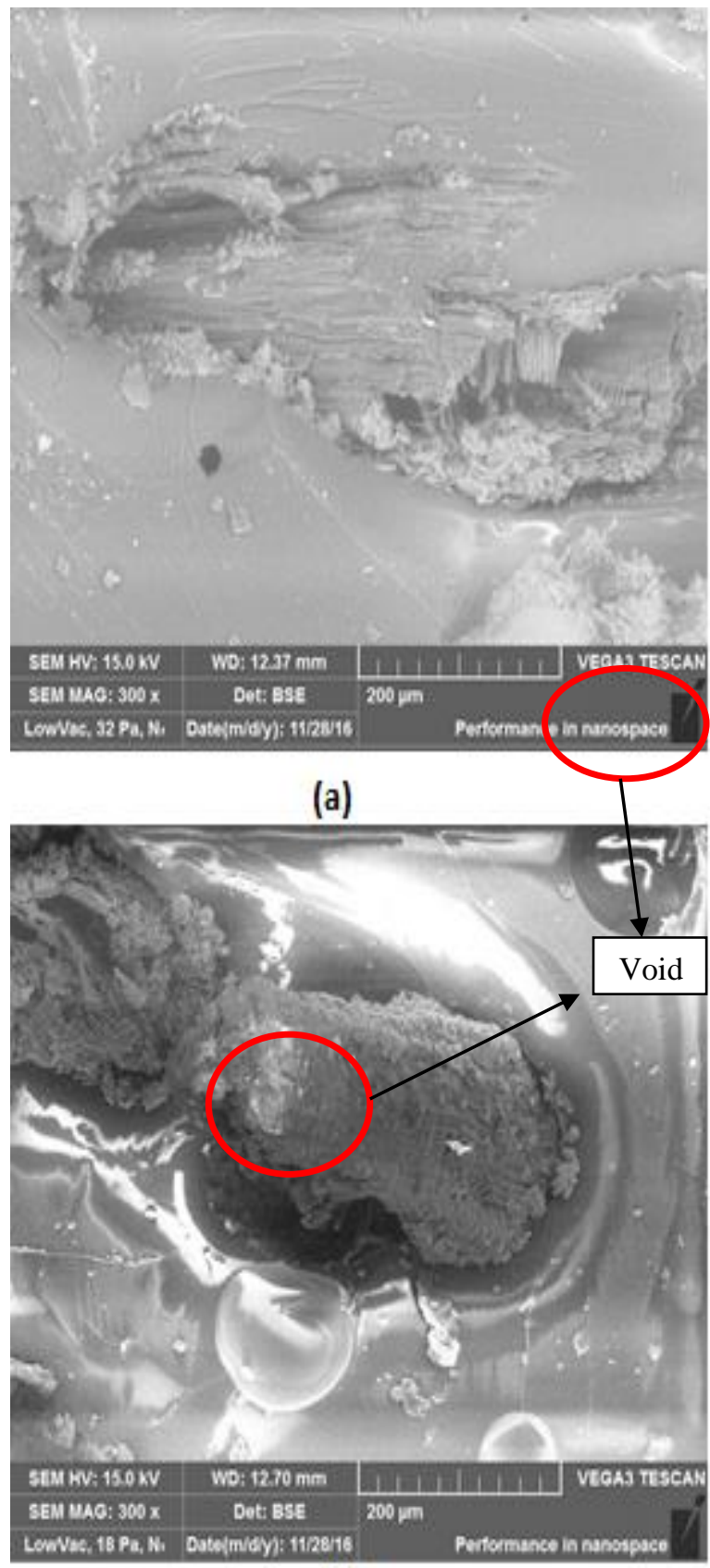

(b)

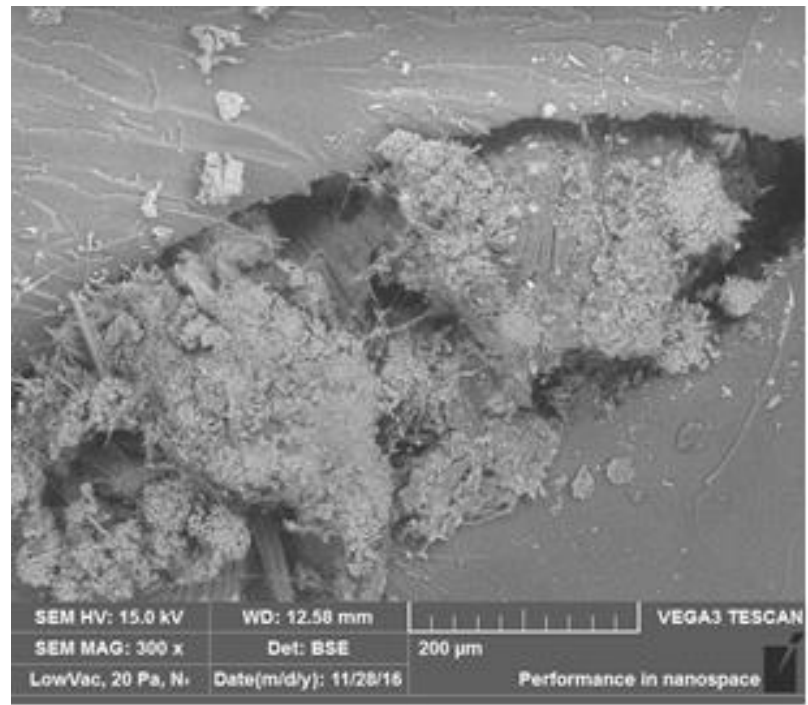

(c)

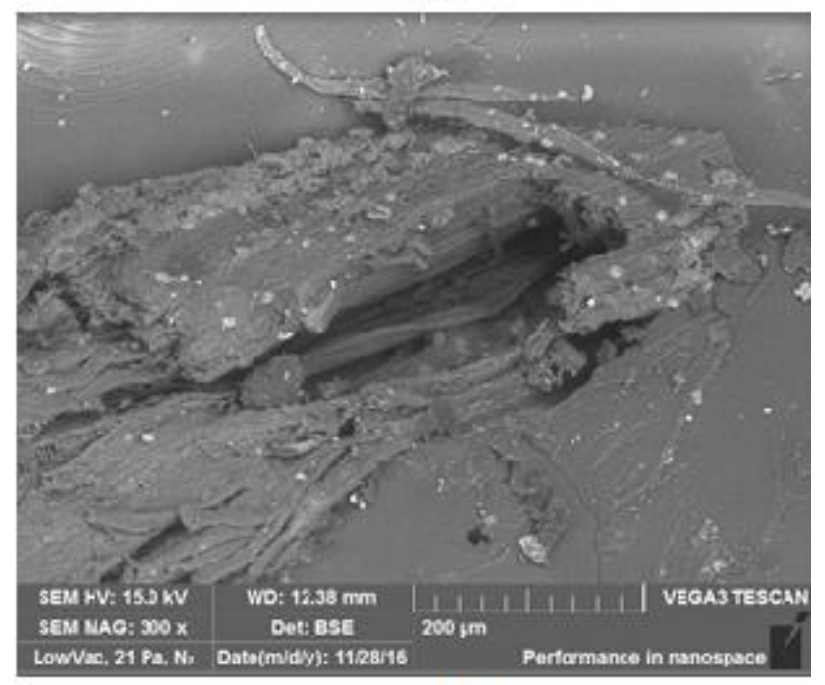

(d)

Gambar 9. (a) Sebelum perendaman, (b) 3 hari setelah perendaman, (c) 6 hari setelah perendaman (d) 9 hari setelah perendaman

\section{Kesimpulan}

Adapun kesimpulan dari penelitian ini yaitu, laju penyerapan mencapai kenaikan tertinggi pada hari pertama yaitu $0,26 \%$ untuk spesimen pertama pengujian 3 hari, 0,5\% untuk spesimen kedua pengujian 6 hari dan $0,25 \%$ untuk spesimen ketiga pengujian 9 hari. Kemudian akan berlangsung stabil dan menurun sampai mencapai titik jenuh. Dimana untuk spesimen pertama di hari ketiga penyerapannya $0,49 \%$, spesimen kedua di hari keenam penyerapannya $1,71 \%$, dan spesimen ketiga di hari kesembilan penyerapannya $0,93 \%$. Dan pengaruh 
perendaman air laut terhadap kekuatan tarik komposit berpenguat serat pelepah sawit ini memiliki dampak yang dinamis untuk hasil uji sebelum perendaman sampai ke 9 hari perendaman yaitu kekuatan yang naik dan turun. Dengan nilai $15,468 \mathrm{MPa}$ sebelum perendaman, 17,046 MPa 3 hari perendaman, 15,107 $\mathrm{MPa} 6$ hari perendaman, dan 21,137 $\mathrm{MPa} 9$ hari perendaman.

\section{Ucapan Terima Kasih}

Kegiatan penelitian ini terlaksana atas bantuan dari Kementrian Riset, Teknologi dan Pendidikan Tinggi, baik bantuan dana melalui hibah penelitian dosen pemula Kemenristekdikti melalui P3M Poltekba, serta kepada toolman dan admin Program Studi Teknik Alat Berat Poltekba atas bantuannya dalam membantu pengambilan data. Oleh karena itu, kami tak lupa mengucapkan terima kasih..

\section{Daftar Pustaka}

[1] Departemen Kelautan dan Perikanan, Direktorat Jenderal Perikanan Tangkap, 2008. Jakarta,Petunjuk Pelaksanaan Pengelolaan Pelabuhan Perikanan,

[2] Seketariat Jenderal Kementerian Kelautan dan Perikanan, 2012. Statistik Perikanan Tangkap, Perikanan Budidaya, dan EksporImpor 2003-2010. Jakarta, Kementerian Kelautan dan Perikanan.

[3] Robby Tamba, "Studi Pengaruh Perendaman Menggunakan Air Laut Pada Kayu Meranti Merah Terhadap Kekuatan Kayu" Teknika Teknika Vol 6, No 2.2005.

[4] Errajhi, O.A.Z, Osborne, J.R.F, Richardson, M.O.W, Dhakal, H.N.,,Water Absorption Characteristic of Aluminised E-glass Fibre Reinforced Unsaturated Poliéster Composites, Composite Structures, Vol. 71, No. 3-4, 02.11.2005, p. 333-336.

[5] Wang, W, Sain, M, Copper, P.A. 2005,Study of Moisture Absorption in NaturalFiber Plastic Composites, Composites Science and Technology 66 (2006) 379-386.

[6] http://ditjenbun.pertanian.go.id/berita-362-pertumbuhan-arealkelapa-sawit-meningkat.html

[7] S Achmadi,Pengaruh Intensitas pencahayaan terhadap arah pertumbuhan kelapa sawit, Departemen Pertanian Fakultas Pertanian USU,2006. Medan. 